\title{
Impact of Moderate Intensity Pulsed Electric Field (MIPEF) Treatment on Lycopene Content and Lycopene In VitroBioaccessibility of Whole Tomato
}

\author{
K.G.L.R. Jayathunge ${ }^{*}$, Alexandros Stratakos ${ }^{1}$, Oliver Cregenzán-Albertia ${ }^{2}$, Irene R. Grant ${ }^{1}$, \\ James Lyng ${ }^{2}$ and Anastasios Koidis ${ }^{1}$
}

Institute for Global Food Security

Queen's University Belfast, Belfast

Northern Ireland, UK.

\begin{abstract}
In this study, the impact of moderate intensity pulsed electric field (MIPEF) treatment parameters on enhancing the lycopene content and lycopene in vitro bioaccessibility was investigated. In the first experiment, tomato fruits were treated at $0.4,1$ and $2 \mathrm{kV} / \mathrm{cm}$ using 1 or 10 monopolar pulses of $4 \mu \mathrm{s}$ at a frequency of $0.1 \mathrm{~Hz}$ and analysed $24 \mathrm{~h}$ after holding period at $4{ }^{\circ} \mathrm{C}$ while in the second experiment, the influence of treatment intensity (0, 4, 80 and $320 \mu \mathrm{s})$ and holding period (0, 24 and $48 \mathrm{~h})$ on lycopene contents and lycopene in vitro bioaccessibility was evaluated. Fresh sample, without MIPEF treatment, showed the lowest lycopene content $(23.27 \pm 2.13 \mu \mathrm{g} / \mathrm{g} \mathrm{FW})$ and the lowest lycopene bioaccessibility $(8.1 \pm 1.70 \%)$, while all MIPEF treatments (4 or $40 \mu \mathrm{s})$ at different electric field strength $(0.4-2.0 \mathrm{kV} / \mathrm{cm})$ enhanced the lycopene content and lycopene bioaccessibility. The results of second experiment revealed that the highest duration treatment (320 $\mu \mathrm{s})$ showed the maximum lycopene enhancement immediately after the treatment (57.98 4.48 $\mu \mathrm{g} / \mathrm{g}$ ) and decreased thereafter. All the treatments except $320 \mu \mathrm{s}$ sample enhanced the lycopene invitrobioaccessibility after $24 \mathrm{~h}$ after holding period and decreased thereafter. The maximum total lycopene bioaccessibility content (9.6\%) of whole tomato was achieved by a $4 \mu \mathrm{s}($ at $1 \mathrm{kV} / \mathrm{cm})$ treatment after a $24 \mathrm{~h}$ holding period.
\end{abstract}

Keywords: Bioaccessibility, lycopene, moderate intensity pulsed electric field, tomato

\section{INTRODUCTION}

Interest in the bioaccessibility of vitamins and other food components (i.e., carotenoids) has greatly increased for different reasons, including the existence of undernourished populations worldwide and groups at risk of developing micronutrient deficiencies. Among micronutrients available in fruits and vegetables, lycopene is an important carotenoid which has shown the epidemiological evidence suggesting protective effects against several diseases such as cancer, cardiovascular diseases, cataracts and neural tube defects (Campbell et al., 2004). Tomato is a popular fruit crop which contains significant amount of lycopene. However, studies have indicated the on low lycopene bioaccessibility of tomato products (Stahl and Sies, 1992; Svelander et al., 2010). Therefore, it is a challenge to investigate

\footnotetext{
1 Institute for Global Food Security, Queen's University Belfast, Belfast, Northern Ireland, UK.

2 School of Agriculture and Food Science, University College Dublin, Ireland

* Author of correspondence : lasanthijayathunge@yahoo.com
} 
optimum processing conditions that can result in maximum overall lycopene bioaccessibility and bioavailability.

Pulsed electric field (PEF) treatment is a one of the widely investigated technologies during last few decades among different non-thermal processing technologies (Rasoet al., 1998; Nguyen and Mittal, 2007; Odriozola-Serrano et al., 2007; 2008a,b; 2009; MosquedaMelgaret al., 2012) as an alternative to thermal processing. In addition to processing, there has been increasing interest in the use of moderate intensity pulsed electric field (MIPEF) technology due to its potential to induce non-thermal permeabilisation and stress reaction at cellular level in the plant (Soliva-Fortunyet al., 2009). This permeabilisation and stress reactions have been reported to be beneficial in enhancing and stimulating total polyphenolic and carotenoid content in plants (Balasaet al., 2006; Toepflet al., 2006; Vallverdu-Queraltet al., 2013). However, no information is available concerning the effect of MIPEF on lycopene bioaccessibility of tomato fruits or their products.

Hence, this study was conducted to study the impact of MIPEF treatment parameters in changing the lycopene content and in vitro lycopene bioaccessibility of tomato fruit.

\section{MATERIALS AND METHODS}

\section{Materials}

Tomato fruits of Pitenza (origin- Spain) variety at fully ripe stage (peel colour-fully red, TSS content- $5^{\circ}$ Brix) were purchased in several batches from a local store in Northern Ireland (UK) between December 2014 and July 2015. In total, $60 \mathrm{~kg}$ of tomatoes were purchased in six batches and graded before processing (mean weight, $85 \pm 5 \mathrm{~g}$ and mean circumference, $15 \pm 1 \mathrm{~cm}$ ); odd shaped and sized tomatoes were excluded. All chemicals were purchased from Sigma-Aldrich (Dorset, UK). Packaging materials (polyethylene/polyamide film, 200 $\mu \mathrm{m}$ thickness) were obtained from Scobie\&Junor (Mallusk, UK).

\section{Methods}

\section{Determination of theEffect of Electric Field Strength (EFS)}

MIPEF treatments were conducted in batch mode using a laboratory scale PEF unit (C-tech Innovations Ltd, Capenhurst, UK) located in University College Dublin. A stainless steel parallel treatment chamber with $8 \mathrm{~cm}$ gap was used. A tomato fruit was placed in the treatment chamber and filled with tap water. Tomato fruits were treated at $0.4,1$ and 2 $\mathrm{kV} / \mathrm{cm}$ using 1 or 10 monopolar pulses of $4 \mu \mathrm{s}$ at a frequency of $0.1 \mathrm{~Hz}$, according to Vallverdu-Queraltet al. (2013). MIPEF-treated fruits were collected and immediately refrigerated at $4{ }^{\circ} \mathrm{C}$ for $24 \mathrm{~h}$. Fresh untreated tomatoes were also stored separately at $4{ }^{\circ} \mathrm{C}$ for $24 \mathrm{~h}$. Each treatment consisted of three replicates and six fruits were included within each replicate. The whole experiment was conducted within two days using independent batches. Samples were stored at $-80^{\circ} \mathrm{C}$ after the $24 \mathrm{~h}$ holding period until analysis commenced. Total lycopene content and lycopene invitrobioaccessibility was calculated for all treatments after homogenisation with T25 Ultra-Turrax homogeniser (IKA ${ }^{\circledR}$ Werke GmbH, Germany) and suitable EFS was selected for further experiments. 


\section{Determination of theEffect of Treatment Duration and Holding Period}

Whole ripe tomatoes were subjected to $0,1,20,80$ mono-polar pulses $(4 \mu \mathrm{s}$, frequency of $0.1 \mathrm{~Hz}$, EFS $1 \mathrm{kV} / \mathrm{cm}$ ), which is equivalent to $0,4,80$ and $320 \mu$ s treatment duration respectively, using a laboratory scale PEF unit as described in the above section. MIPEF treated and untreated fruits were collected and immediately refrigerated at $4{ }^{\circ} \mathrm{C}$ for $48 \mathrm{~h}$. Each treatment consisted of three replicates with six fruits per replicate and the whole experiment was conducted on two separate days as independent batches. Samples were withdrawn after 0, 24 and $48 \mathrm{~h}$ and subjected to analysis. Samples were stored at $-80{ }^{\circ} \mathrm{C}$ until analysis andtotal lycopene content and lycopene invitrobioaccessibility were evaluated.

\section{Quality Analysis \\ Quantification of Total Lycopene Content of Tomatoes}

Lycopene content of freeze dried tomato extracts was determined colorimetrically using the method described by Sadler et al. (1990). Lycopene was extracted from freeze dried samples using hexane:ethanol:acetone, 2:1:1 $(0.05 / 50 \mathrm{ml})$ mixture. The hexane phase, containing lycopene, was separated from the polar phase and absorbance of the lycopene extract was measured at $472 \mathrm{~nm}$ using UV/vis spectrophotometer (JENWAY 6305, UK) against the hexane blank. Concentration of lycopene was calculated using the following equation:

$$
C=\frac{A \times 10^{4}}{E^{*} 1 \mathrm{~cm} \times l}
$$

Where, $\mathrm{C}$ is the lycopene concentration $(\mu \mathrm{g} / \mathrm{ml})$, Ais the absorbance at $472 \mathrm{~nm}, \mathrm{E}^{\%}{ }_{1 \mathrm{~cm}}$ is the extinction coefficient (3450 for lycopene in hexane) at a path length of $1 \mathrm{~cm}$.

\section{Determination of InvitroBioaccessibilityLycopene}

Tomato samples $(2.5 \mathrm{~g})$ were subjected to a simulated human gastric and small intestinal digestion based on the method described by Garrett et al. (1999) and Hedrenet al. (2002) with minor modifications (Colleet al., 2010; Aneseet al., 2013) to determine the in vitro bioaccessibility of lycopene. All steps were carried out under protection from light using amber tubes and vials.

Gastric digestion simulation: A NaCl/ascorbic acid solution (2.5. ml) $(0.9 \% \mathrm{NaCl}, 1 \%$ ascorbic acid in water) and a stomach electrolyte $(2.5 \mathrm{ml}, 0.30 \% \mathrm{NaCl}, 0.11 \% \mathrm{KCl}, 0.15 \%$ $\mathrm{CaCl}_{2} .2 \mathrm{H}_{2} \mathrm{O}, 0.05 \% \mathrm{KHPO}_{4}, 0.07 \% \mathrm{MgCl}_{2} .6 \mathrm{H}_{2} \mathrm{O}$ in water) were added to $2.5 \mathrm{~g}$ of sample. The $\mathrm{pH}$ of this mixture was adjusted to $4 \pm 0.05$ (with $1 \mathrm{M} \mathrm{HCl}$ ) before the addition of pepsin solution $(0.52 \%$ porcine pepsin in stomach electrolyte). Subsequently, the headspace of the tubes was flushed with nitrogen and the mixture was incubated for $30 \mathrm{~min}$ at $37^{\circ} \mathrm{C}$ while shaking. Before continuing the incubation for $30 \mathrm{~min}$, the mixture was acidified to $\mathrm{pH}$ $2 \pm 0.05$ (with $1 \mathrm{M} \mathrm{HCl}$ ) and the headspace was flushed again with nitrogen. The adjustment of the $\mathrm{pH}$ in two steps mimicked the gradual drop of the gastric $\mathrm{pH}$ after the intake of a meal.

Small intestinal digestion simulation: The $\mathrm{pH}$ of the partially digested tomato pulp was raised to $\mathrm{pH} 6.9 \pm 0.05$ (with $1 \mathrm{M} \mathrm{NaOH}$ ) and a mixture of pancreatin, lipase, and bile salts ( $1.5 \mathrm{ml}, 0.4 \%$ porcine pancreatin, $0.2 \%$ porcine pancreas lipase, $2.5 \%$ bile extract, $0.5 \%$ 
pyrogallol, $1 \% \alpha$-tocopherol in water) was added. Finally, the headspace of the sample was flushed with nitrogen and the sample was incubated for $2 \mathrm{~h}$ at $37^{\circ} \mathrm{C}$.

After incubation, the samples were centrifuged (SORVALL Legend RT, Woburn, Germany) at $5000 \mathrm{~g}$ for $1 \mathrm{~h}$ to remove the non-digested particles. The lycopene concentration in the supernatant was then measured using the spectrophotometric and HPLC methods described below. The lycopene bioaccessibility of a sample is reported as the ratio (\%) of the in vitro bioaccessible lycopene content to the corresponding lycopene content of the sample.

\section{Statistical Analysis}

Significance of the results and statistical differences were analysed using the SPSS (IBM, UK) statistical package. Data were analysed by two-way analysis of variance (ANOVA) procedure. Duncan multiple range test (DNMRT) was employed to determine the differences among treatment means, with a level of significance of $\mathrm{P}<0.05$.

\section{RESULTS AND DISCUSSION}

\section{Effect of Electrical Field Strength (EFS) on Total Lycopene Content and Lycopene In VitroBioaccessibility of Tomato Fruits}

The total lycopene content of fresh and MIPEF treated fruits (undigested) and digesta (digested) of corresponding treatments, analysed by spectrophotometric method and calculated percentage in vitrobioaccessibility is given in Table 1. The fresh sample (without PEF treatment) showed the lowest lycopene content $(23.27 \pm 2.13 \mu \mathrm{g} / \mathrm{g} F W)$ and were within the range described in the literature (Svelanderet al., 2010). Similarly, retention of lycopene content in digested untreated samples was $1.88 \pm 0.29 \mu \mathrm{g} / \mathrm{g} \mathrm{FW}$, resulting in $8.1 \pm 1.70 \%$ bioaccessibility. Investigations of the in vitro bioaccessibility of lycopene from tomato are very limited, but values reported for the digesta are fairly low and in the range of $2-13 \%$ of total content (Stahl and Sies, 1992; Gartner et al., 1997; Svelanderet al., 2010).

All MIPEF treatments (4 or $40 \mu \mathrm{s})$ at different electric field strengths $(0.4-2.0 \mathrm{kV} / \mathrm{cm})$ enhanced the lycopene concentration, and $40 \mu$ s treatment at $1 \mathrm{kV} / \mathrm{cm}$ EFS showed $50 \%$ lycopene enhancement in comparison to fresh control samples. The lycopene concentration in digesta of MIPEF treated fruits significantly increased in comparison to untreated fruits and EFS of $1 \mathrm{kV} / \mathrm{cm}, 4 \mu$ s treatment showed the highest lycopene content $(3.37 \pm 0.12 \mu \mathrm{g} / \mathrm{g}$ FW). The results show that MIPEF treatment is able to increase production and availability for digestion of lycopene in plant tissues. Vallverdu-Queralt (2013) also reported that application of $1.2 \mathrm{kV} / \mathrm{cm}$ EFS and $20 \mu \mathrm{s}$ (5 pulses) treatment duration enhances the carotenoid content of tomatoes, including lycopene in comparison to 0.4 and $2 \mathrm{kV} / \mathrm{cm}$ EFS levels. 
Table 1. Effect of MIPEF treatment of whole tomatoes (6 per treatment) on total lycopene content and lycopene bioaccessibility.

\begin{tabular}{|c|c|c|c|c|}
\hline \multicolumn{2}{|c|}{ Treatment } & \multirow{2}{*}{$\begin{array}{c}\text { Amount present in } \\
\text { undigested samples } \\
(\mu \mathrm{g} / \mathrm{g})\end{array}$} & \multirow{2}{*}{$\begin{array}{c}\text { Amount present in } \\
\text { digesta } \\
(\mu \mathrm{g} / \mathrm{g})\end{array}$} & \multirow{2}{*}{$\begin{array}{c}\text { Lycopene } \\
\text { bioaccessibility } \\
(\%)\end{array}$} \\
\hline $\begin{array}{c}\text { EFS } \\
(\mathrm{kV} / \mathrm{cm}) \\
\end{array}$ & $\begin{array}{c}\text { Time } \\
(\mu \mathrm{s})\end{array}$ & & & \\
\hline Fresh & 0 & $23.27 \pm 2.13 b$ & $1.88 \pm 0.29 \mathrm{c}$ & $8.1 \pm 1.70 \mathrm{c}$ \\
\hline 0.4 & 4 & $27.71 \pm 0.99 b$ & $2.79 \pm 0.16 b$ & $10.07 \pm 0.56 \mathrm{~b}$ \\
\hline 1.0 & 4 & $27.43 \pm 3.21 b$ & $3.37 \pm 0.12 \mathrm{a}$ & $12.46 \pm 1.98 \mathrm{ab}$ \\
\hline 2.0 & 4 & $28.18 \pm 4.75 \mathrm{ab}$ & $3.13 \pm 0.36 \mathrm{ab}$ & $11.18 \pm 0.75 b$ \\
\hline 0.4 & 40 & $29.35 \pm 8.04 \mathrm{ab}$ & $3.05 \pm 0.13 \mathrm{ab}$ & $10.87 \pm 2.63 b$ \\
\hline 1.0 & 40 & $34.97 \pm 3.02 \mathrm{a}$ & $3.27 \pm 0.05 \mathrm{a}$ & $9.41 \pm 0.90 c$ \\
\hline 2.0 & 40 & $24.91 \pm 0.28 \mathrm{~b}$ & $3.28 \pm 0.30 \mathrm{a}$ & $13.15 \pm 1.08 \mathrm{a}$ \\
\hline
\end{tabular}

Values are means \pm standard deviation. Values within each column followed by the same letter are not significantly different at $\mathrm{p}<0.05$.

It is already known that MIPEF processing may activate enzymes needed for carotenoid and phenol synthesis and stimulate the production of secondary metabolites of different fruits and vegetables (Cunningham and Gantt, 1998). For instance, an improvement (51-67\%) of $\beta$-carotene extraction efficiency of carrot juice (Knorr et al., 1994) and an increase (13-28\%) of total phenolic content of grape juice (Balasa et al., 2006) has been reported. According to Heinz et al. (2003), critical EFS needed to induce membrane permeabilisation is dependent on cell geometry and size, and a dose of $1-2 \mathrm{kV} / \mathrm{cm}$ of EFS is required for plant cells (cell size 40-200 mm). However, high intensity treatments also have been proven effective in cell membrane permeabilisation and total polyphenol extractability in grape marc (Balasaet al., 2006).

Here, the highest in vitrobioaccessibilities of $13.15 \pm 1.08$ and $12.46 \pm 1.98 \%$ were achieved with treatments of $2 \mathrm{kV} / \mathrm{cm}, 40 \mu \mathrm{s}$ and $1 \mathrm{kV} / \mathrm{cm}, 4 \mu \mathrm{s}$, respectively (Table 5.1). The treatments were not significantly different although using $1 \mathrm{kV} / \mathrm{cm}$ would be more economical in comparison to $2 \mathrm{kV} / \mathrm{cm}$. Hence, the EFS of $1 \mathrm{kV} / \mathrm{cm}$ was chosen to perform other experiments since it yielded high lycopene extraction both in digested and undigested samples.

\section{Effect of MIPEF Treatment Parameters on Lycopene Content and Lycopene InvitroBioaccssibility of Tomato Fruits}

Lycopene content in fresh tomatoes remained stable during $48 \mathrm{~h}$ holding period without significant differences at $\mathrm{p}<0.05$ (Fig.1). In contrast to fresh tomatoes, lycopene concentrations were enhanced after the MIPEF treatment of tomato. Moreover, lycopene concentrations of $4 \mu \mathrm{s}$ and $80 \mu$ s treatments further increased with extension of the holding period up to 24 and $48 \mathrm{~h}$ (Fig.1) which is in line with the literature (Soliva-Fortunyet al., 2009; Vallverdu-Queraltet al., 2013). The highest duration treatment (320 $\mu$ s) showed the maximum lycopene enhancement immediately after the treatment $(57.98 \pm 4.48 \mu \mathrm{g} / \mathrm{g} \mathrm{FW})$ and decreased thereafter. This might be due to lethal damage to cells due to irreversible loss of cell membrane permeability properties (Zimmermann et al., 1974; Aronsson et al., 2001). Similar decreases in lycopene contents were reported by Vallverdu-Queralt et al (2013) for MIPEF treated $(2 \mathrm{kV} / \mathrm{cm}, 120 \mu \mathrm{s})$ tomato $24 \mathrm{~h}$ after the treatment. 
According to two-way ANOVA, total lycopene contents of fresh tomatoes (both undigested and digested) were not significanly different until $24 \mathrm{~h}$ and showed significant increase $(32.35 \pm \mu \mathrm{g} / \mathrm{g})$ after $48 \mathrm{~h}$. Tomatoes treated with $4 \mu \mathrm{s}$ showed significant increase in total lycopene content $48 \mathrm{~h}$ (undigested) and $24 \mathrm{~h}$ (digested) after treatment. On the other hand, 80 us treated samnles (undigested) showed non-significant changes throughout the the holding

A

$\multimap$ Undigested $\rightarrow$ Digesta

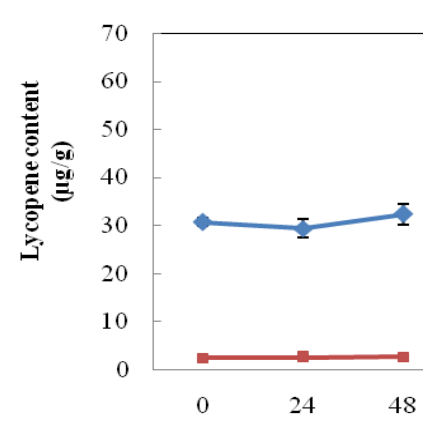

Time after treatment (h)
B
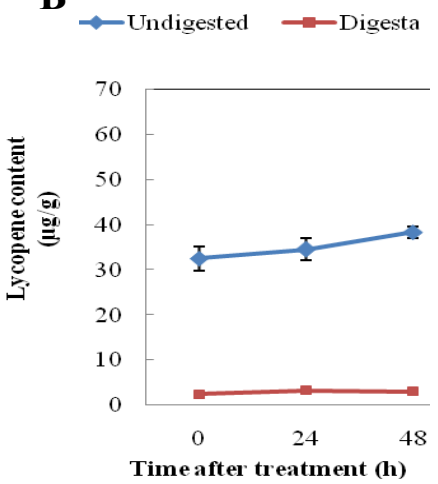

in total

$\mathbf{C}$

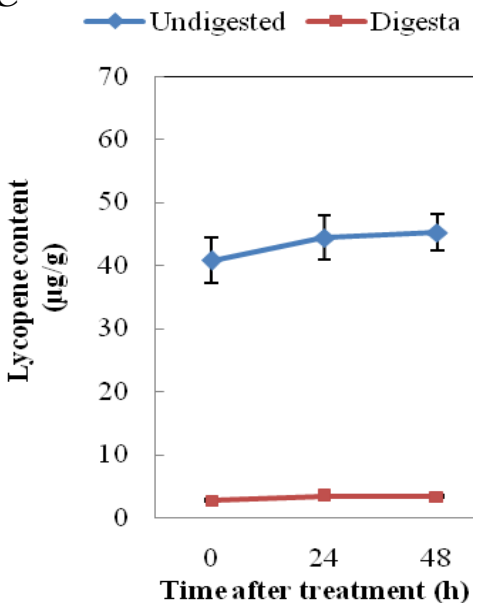

$\mathbf{D}$
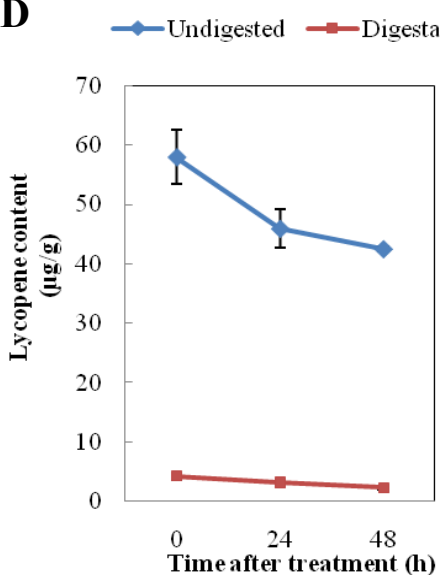

Fig. 1. Impact of MIPEF treatment and holding period on lycopene concentration of whole tomato. Fresh tomato (A), $4 \mu \mathrm{s}$ (B), $80 \mu \mathrm{s}$ (C), $320 \mu \mathrm{s}$ (D), n=3. 
The effect of treatment duration and holding period (at $4{ }^{\circ} \mathrm{C}$ ) on lycopene invitro bioaccessibility of whole tomato is shown in Fig.2.

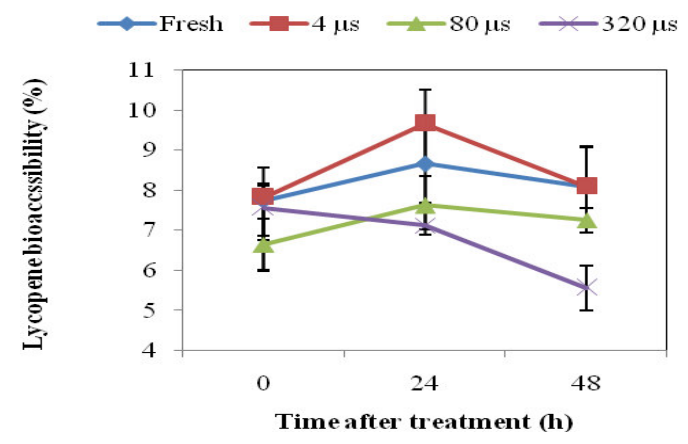

Fig.2. Impact of MIPEF treatment and holding period on lycopene invitro bioaccessibilioty of whole tomato. Fresh tomato (A), $4 \mu \mathrm{s}$ (B), $80 \mu \mathrm{s}$ (C), $320 \mu \mathrm{s}$ (D), $\mathbf{n = 3}$.

Release and subsequent absorption of lycopene from raw tomato is low and Svelanderet al.(2010) reported that $5-13 \%$ bioaccessibility for crushed fresh tomatoes. Similarly, the lycopene invitro bioaccessibility of untreated samples were in the range of 7.7-8.6\% and remained non-signifiamt during the $48 \mathrm{~h}$ holding period, which agrees with the litertaure. For the treated samples, the lowest duration treatment $(4 \mu \mathrm{s})$ showed non-significant increment while rest of the treatments $(80$ and $320 \mu \mathrm{s})$ decreased the invitro bioaccessibility immediately after the treatment (Figure 2). Results show that with an increasing MIPEF intensity, the lycopene invitrobioaccessibility was significantly reduced $(\mathrm{P}<0.05)$. The lycopene bioaccessibilities investigated after $24 \mathrm{~h}$ holding period were 8.60, 9.64, 7.59 and $7.11 \%$ for fresh, 4, 80 and $320 \mu \mathrm{s}$ MIPEF treatments, respectively and all the levels were enhanced after $24 \mathrm{~h}$ holding period in comparison to the value investigated immediately after the treatment except for the highest duration treatment $(320 \mu \mathrm{s})$. However, the lycopene bioaccessibility of all treatments reduced drastically $48 \mathrm{~h}$ after the treatment irrespective of the treatment intensity. This decrement might suggest that lycopene became entrapped by process induced barriers, thus hindering its subsequent incorporation into micelles.

No systematic studies, neither in vivo orin vitro, that report lycopene bioaccessibility in tomato as affected by MIPEF technology seem to exist currently. Studies conducted on thermal processing (Palmeroet al., 2014), in red tomatoes, reported that the lycopene bioaccessibility is mostly depend on the barrier properties of the chromoplast. Therefore, this structural barrier would be an important target tobe modified upon any processing treatments applied.

\section{CONCLUSIONS}

The results of this study clearly demonstrate the benefit of MIPEF as a treatment to enhance the lycopene bioaccessibility of whole tomato. Total carotenoid and lycopene contents could be enhanced by increasing the treatment duration (from 4-320 $\mu \mathrm{s}, \mathrm{EFS}-1 \mathrm{kV} / \mathrm{cm}$ ) due to cell 
permeabilisation as reported previously. The lowest duration $(4 \mu \mathrm{s})$ treatment showed the highest total lycopene bioaccessibility $(9.6 \%)$ after a $24 \mathrm{~h}$ holding period.

\section{ACKNOWLEDGEMENTS}

This research was carried out undera $\mathrm{PhD}$ scholarship programme of the Commonwealth Scholarship Commission, UK

\section{REFERENCES}

Anese, M., Mirolo, G., Beraldo, P. and Lippe, G. (2013).Effect of ultrasound treatments of tomato pulp on microstructure and lycopene in vitro bioaccessibility.Food Chem.136, 458 463.

Aronsson, K., Lindgren, M., Johansson, B.R. and Ronner, U. (2001). Inactivation of microorganisms using pulsed electric fields: the influence of process parameters on Escherichia coli, Listeria innocua, Leuconostocmesenteroides and Saccharomyces cerevisiae. Innov.Food Sci. Emerg. Technol.2, 41 - 54.

Balasa, A., Toepfl, S. and Knorr, D. (2006). Pulsed electric field treatment of grapes. Food Factory of the Future 3, Gothenburg, Sweden.

Campbell, J.K., Canene-Adams, K., Lindshield, B.L., Boileau, T.W.M., Clinton, S.K. and Erdman, Jr.J.W. (2004). Tomato phytochemicals and prostate cancer risk. J.Nutri. 134, $3486 \mathrm{~S}-3492 \mathrm{~S}$

Colle, I., Van Buggenhout, S., Van Loey, A. and Hendrickx, M.E. (2010). High pressure homogenation followed by thermal processing of tomato pulp: influence on microstructure and lycopene invitrobioaccessibility. Food Res. Int.43, 2193 - 2200

Cunningham, F.X. and Gantt, E. (1998).Genes and enzymes of carotenoid biosynthesis in plants.Annu. Rev. Plant Physiol. Plant Mol. Biol.49, 557 - 583

Garrett, D.A., Failla, M.I. and Sarama, R.J. (1999).Development of an invitro digestion method to assess carotenoid bioavailability from meals.J. Agric. Food Chem.4, 4301 - 4309.

Gartner, C., Stahl, W. and Sies, H. (1997). Lycopene is more bioavailable from tomato paste than from fresh tomatoes. Am. J.Clin.Nutr.66, 116 - 122.

Hedren, E., Mulokozi, G. and Svanberg, U. (2002).Invitrobioaccessibility of carotenes from green leafy vegetables cooked with sunflower oil or red palm oil. Int.J.Food Sci.Nutr.53, 445 $-453$.

Heinz, V., Toepfl, S. and Knorr, D. (2003).Impact of temperature on lethality and energy efficiency of apple juice pasteurization by pulsed electric fields treatment.Innov.Food Sci. Emerg.Technol.4, 167 - 175.

Knorr, D., Geulen, M., Grahl, T. and Sitzmann, W. (1994). Food application of high electric field pulses. Trends Food Sci. Technol. 5(3), 71 - 75. 
Mosqueda-Melgar, J., Raybaudi-Massilia, R.M. and Martín-Belloso, O. (2012).Microbiological shelf life and sensory evaluation of fruit juices treated by high intensity electric fields and antimicrobials. Food Bioprod.Process.90(2), 205 - 214.

Nguyen, P. and Mittal, G.S. (2007). Inactivation of naturally occurring microorganisms in tomato juice using pulsed electric field (PEF) with and without antimicrobials.Chem. Eng. Process.46, 360 - 365.

Odriozola-Serrano.I., Aguilo-Aguayo.I., Soliva-Fortuny.R., Gimeno-Ario.V. and MartínBelloso, O. (2007). Lycopene, vitamin C, and antioxidant capacity of tomato juice as affected by high-intensity pulsed electric fields critical parameters. J. Agric. Food Chem.55, 9036-9042.

Odriozola-Serrano, I., Solivia-Fortuny, R. and Martin-Belloso, O. (2008b). Changes of health-related compounds throughout cold storage of tomato juice stabilized by thermal or high intensity pulsed electric field treatments. Innov.Food Sci.Emerg. Technol.9, 272 - 279.

Odriozola-Serrano, I., Solivia-Fortuny, R., Gimeno-Ano, V. and Martin-Belloso, O. (2008a).Modeling changes in health-related compounds of tomato juice treated by highintensity pulsed electric fields. J. Food Eng.89, 210 - 216.

Odriozola-Serrano, I., Solivia-Fortuny, R., Hernandez-jover, T. and Martin-Belloso, O. (2009). Carotenoid and phenolic profile of tomato juices processed by high-intensity pulsed electric fields compared with conventional thermal treatments. Food Chem.112, 258 - 266.

Palmero, P., Lemments, L., Hendrickx, M. and Loey, A.V. (2014).Role of carotenoid type on the effect of thermal processing on bioaccessibility.Food Chem. 157, 275 - 282.

Raso, J., Calderon, M.L., Gongora, M., Barbosa-Canovas, G. and Swanson, B.G. (1998).Inactivation of moldsascospores and conidiospores suspended in fruit juices by pulsed electric fields.LWT- Food Sci. Technol. 31, 668 - 672.

Sadler, G., Davis, J. and Dezman, D. (1990).Rapid extraction of lycopene and $\beta$-carotene from reconstituted tomato paste and pink grapefruit homogenate.J. Food Sci.55, 1460 - 1461.

Soliva-Fortuny, R., Balasa, A., Knorr, D. and Martin-Belloso, O. (2009). Effects of pulsed electric fields on bioactive compounds in foods: a review. Trends Food Sci. Technol.20, 544 $-556$.

Stahl, W. and Sies, H. (1992). Uptake of lycopene and its geometrical isomers is greater from heat-processed than from unprocessed tomato juice in humans. J.Nutr.122, 2162 2166.

Svelander, C.A., Tiback, E.A., Ahrne, L.M., Langton, M.I.B.C., Svanberg, U.S. and Alminger, M.A.G. (2010).Processing of tomatoes: impact on invitrobioaccessibility of lycopene and textural properties.J. Sci. Food Agric.90, 1665 - 1672.

Toepfl, S., Mathys, A., Heinz, V. and Knorr, D. (2006).Potential of high hydrostatic pressure and pulsed electric fields for energy efficient and environmentally friendly food processing.Food Rev. Int. 22, 405 - 423. 
Jayathunge et al.

Vallverdu-Queralt, A., Oms-Oliu, G., Odriozola-Serrano, I., Lamuela-Raventos, R.M., Martin-Belloso, O. and Elez-Martinez, P. (2013).Matabolite profiling of phenolic and carotenoid contents in tomatoes after moderate intensity pulsed electric field treatments. Food Chem. 136, 199 - 205.

Zimmermann, U., Pilwat, G. and Riemann, F. (1974).Dielectric breakdown of cell membrane.Biophy. J. 14, 881 - 899. 